\title{
Streptokinase neutralisation titres up to 866 days after intravenous streptokinase for acute myocardial infarction
}

\author{
S Patel, S Jalihal, D P Dutka, G K Morris
}

\begin{abstract}
Objective-To follow the change in streptokinase neutralisation titres in a group of patients after treatment with streptokinase for acute myocardial infarction. Design-Venous blood samples suitable for analysis were obtained up to 866 days after treatment with 1.5 million units of streptokinase in 189 patients. The ability of the patient's plasma to inhibit lysis of a thrombin clot by streptokinase was assessed.

Setting-A coronary care unit in a district general hospital.

Patients-A retrospective review of coronary care records and the district health authority computer showed that 329 patients who had received streptokinase were alive. All were invited for venepuncture and 220 (67\%) attended. Satisfactory samples were obtained from 189 patients.
\end{abstract}

Results-Raised titres of antibody sufficient to neutralise a standard dose of 1.5 million units of streptokinase were found in $90 \%$ of patients. There was a fall in streptokinase neutralisation titre with increasing time after administration of streptokinase $\quad(r=-0.35, \quad P<0.0001)$ and though there was considerable variation among the group the neutralisation titre was higher than in the general population in all patients, even those who had received streptokinase at least two

Conclusion-The ability of streptokinase to lyse a thrombin clot was appreciably inhibited in vitro by the plasma from patients who had received 1.5 million units of streptokinase. High streptokinase neutralisation titres persisted for a long time after the use of streptokinase as thrombolytic treatment for acute myocardial infarction. Readministration of streptokinase may not be efficacious for considerably longer than the one year currently advocated. Until the in vivo effects of streptokinase readministration are known a non-antigenic thrombolytic agent should be used instead. Nottingham

S Patel

S Jalihal

S Jalihal

G K Morris

Correspondence to:

Dr $S$ Patel, City Hospital, Huckall Road,

Nottingham, NG5 1PB.

Accepted for publication

23 February 1993

Streptokinase is widely used as a first line thrombolytic agent in the management of acute myocardial infarction. It is cheaper than other thrombolytic agents and most cliniyears previously.

cians, particularly in the United Kingdom, are more familiar with its use than other agents.

Reinfarction after thrombolytic treatment may occur in up to $9 \%$ of patients ${ }^{1}$ though this number may be substantially reduced by the prophylactic use of aspirin. ${ }^{2}$ Effective thrombolysis for reinfarction is needed to preserve ventricular function and improve prognosis in these patients. ${ }^{3}$

Streptokinase is a foreign protein derived from streptococci and is antigenic in man. Antibodies to streptococci are widespread in the general population ${ }^{45}$ and studies of the dose of streptokinase required to induce a thrombolytic state found that a loading dose of 152 000-359000 units was required to overcome these antibodies. ${ }^{6}$ After treatment with streptokinase streptokinase antibody titres increase considerably ${ }^{78}$ and the presence of these antibodies both increases the possibility of an adverse reaction ${ }^{910}$ and may reduce the thrombolytic efficacy of readministered streptokinase. ${ }^{11}$ After the use of 1.5 million units of streptokinase for acute myocardial infarction circulating streptokinase antibody titres initially fell as the antibody is bound to streptokinase and then rose. ${ }^{78}$

Manufacturers of streptokinase recommended that a second dose should not be given between five days and one year after the first because the combination of streptokinase with the antibody may totally neutralise the thrombolytic action of streptokinase. The initial time window when readministration may be considered safe and efficacious may be shorter because significant levels of IgG antibody have been found four days after treatment. The time taken for the antibody titres to fall to a value where a repeated standard dose of streptokinase can be considered effective remains uncertain. The streptokinase resistance titre was found to return to pretreatment values one year after the administration of either streptokinase or anistreplase ${ }^{8}$ but another study found that streptokinase resistance was present in most patients 24 months after receiving streptokinase. ${ }^{12}$

This study was undertaken to assess the extent to which plasma from patients who had received streptokinase up to 866 days previously would inhibit the in vitro lysis of a thrombin clot by streptokinase.
Patients and methods

A retrospective search of the coronary care 
records and the district health authority computer indicated that 329 patients who had received a standard dose of 1.5 million units of streptokinase were still alive. Patients who had received partial doses (because of allergic reactions etc) or who were receiving steroid or other immunosuppressive therapy were excluded. All were contacted by letter and asked to attend the coronary care unit for venepuncture. The study was approved by the local ethics committee and all patients gave informed consent.

Streptokinase neutralisation titres were measured as described elsewhere. ${ }^{11}$ In brief, $75000 \mathrm{IU}$ of streptokinase (Streptase, Hoechst) was diluted in physiological saline to give a range of final concentrations of $100-10000 \mathrm{IU} / \mathrm{ml}$ and bovine thrombin (Kabivitrum) was diluted in double distilled water to give a final concentration of 100 $\mathrm{IU} / \mathrm{ml}$. Fresh frozen plasma from two donors was obtained from the blood bank as controls. A series of test tubes containing $100 \mu \mathrm{l}$ of either the sample of pooled fresh frozen plasma, $5 \mu \mathrm{l}$ of diluted bovine thrombin, and $10 \mu \mathrm{l}$ of the range of streptokinase dilutions was incubated in a water bath a $37^{\circ} \mathrm{C}$ for 10 minutes. The lowest concentration of streptokinase that resulted in clot lysis was noted and the ability of the patient's plasma to neutralise streptokinase calculated. A neutralisation capacity of $500 \mathrm{IU} / \mathrm{ml}$ is the estimated titre that would totally neutralise a standard dose of 1.5 million units of streptokinase in a $70 \mathrm{~kg}$ man.

\section{Results}

Satisfactory samples for analysis were

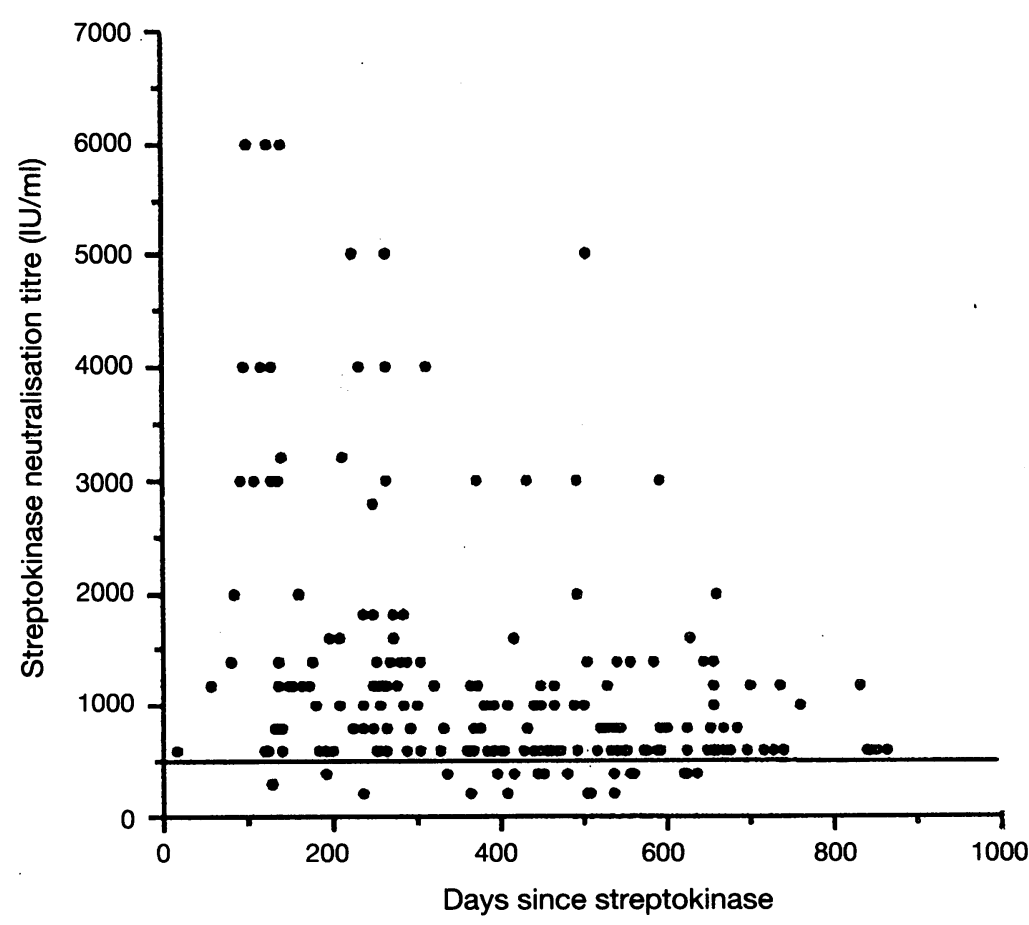

Streptokinase neutralisation titres after treatment with 1.5 million units of streptokinase for acute myocardial infarction in 189 patients. The calculated neutralisation titre for 1.5 million units of streptokinase in a $70 \mathrm{~kg}$ man is $500 \mathrm{IU} / \mathrm{ml}$ (solid line). This totally prevents lysis of a thrombin clot in vitro. obtained from 189 patients (139 men, 50 women, mean age $65 \cdot 6$, range $40-89$ years. The time since administration of streptokinase was $18-866$ days. In only 19 patients $(10 \%)$ had the streptokinase neutralisation capacity fallen below $500 \mathrm{IU} / \mathrm{ml}$ (range 200-400) (figure). All of the patients had neutralisation titres that were at least double those in a similar group of patients with myocardial infarction before treatment with strepto-kinase $^{11}$ (mean $66 \mathrm{IU} / \mathrm{ml}$, range 20-100) and a group of normal healthy volunteers $^{12}$ mean (SEM) 87 (10) IU/ml). As judged indirectly by this in vitro test a conventional dose of 1.5 million units of streptokinase would therefore be partially neutralised in all of these patients. In the 103 patients who had received streptokinase at least one year beforehand the mean (SEM) neutralisation titre was $902(68) \mathrm{IU} / \mathrm{ml}$. A significant correlation was found between time since administration of streptokinase and the neutralisation titre $\left(r=-0.349, r^{2}=0.112\right.$, $p<0.0001)$. There was a wide variation and persistence of high neutralisation titres in some patients after two years, however.

\section{Discussion}

This study was designed to assess the persistence of streptokinase neutralising antibodies after a standard dose of 1.5 million units for acute myocardial infarction and to estimate the interval required before readministration of streptokinase for reinfarction. Reinfarction after thrombolysis occurs in up to $9 \%$ of patient. ${ }^{1}$ Aspirin substantially reduced the risk to about $2 \% .^{2}$ It is not known whether it is safe and effective to re-administer streptokinase to these patients after at least one year has elapsed. Streptokinase is antigenic with possible allergic reactions being reported in $4.4 \%$ of patients who received the drug in ISIS-2 and $3.4 \%$ in GISSI-1 trials. ${ }^{213}$ Patients have antibodies to streptokinase from previous streptococcal infections and the initial dose of 1.5 million units of streptokinase used when they initially present with acute myocardial infarction ensures that these antibodies are overcome. ${ }^{6}$ In patients who have had a recent streptococcal infection, however, the antibody titre may be sufficient to neutralise this dose. ${ }^{45}$

There have been several reports that neutralisation antibodies to streptokinase fall immediately after its use (as the antibody combines with streptokinase), rise to a peak after approximately two weeks, and then decline. ${ }^{81114}$ The height and duration of the antibody response seems to vary but all these studies have found that antibody titres at six months to one year are in excess of pretreatment values in a significant number of patients. The weight of evidence suggests, as does the present study, that streptokinase resistance is present beyond one year. Antibodies were found to be raised at 12 and 24 months in one study, ${ }^{12}$ and in $50 \%$ of patients at 3 and 4 years in another. ${ }^{15}$ This has not been a uniform finding, however, 
with a recent report by Fears $e t a l^{8}$ suggesting that most of a 1.5 million unit dose of streptokinase might be neutralised up to six months but not thereafter.

The relation between streptokinase antibodies and the lytic efficacy of streptokinase in humans is unknown. The in vitro assessment of the ability of the patient's plasma to inhibit lysis of a thrombin clot by streptokinase that we used suggests that the readministration of a conventional dose of streptokinase for reinfarction may not be effective. In an animal model, clot lysis by streptokinase was significantly impaired when streptokinase had been administered one month previously, ${ }^{16}$ and effective thrombolysis was inversely related to the titre of plasma streptokinase antibody. White et al assessed the safety and efficacy of repeat thrombolysis treatment after myocardial infarction in humans and found the infarct related artery to be patent in $70 \%$ of cases after readministration of streptokinase.$^{17}$ Only eight patients, however, received streptokinase twice and an angiogram was performed in six. Three of these six patients reinfarcted within three days (when streptokinase antibody titres are similar to pre-treatment value $)^{78}$ and the remainder five to eight days after their initial treatment with streptokinase. The infarct related vessel was occluded in the patient to whom streptokinase was readministered on day eight, but was patent in the other five patients. The results of such a small study cannot be extra polated.

Unlike Fears $e t a l^{8}$ we found that a significant number of patients had raised titres of streptokinase neutralising antibody beyond one year. Because the fall in antibody titre is not predictable no recommendation can be made about when readministration of streptokinase can be considered safe and effective. It has been suggested that an assay could be used to assess the titre of these antibodies or the neutralisation capacity of the patient's blood before readministration of streptokinase. This approach might have financial advantages but such an assay would have to be readily available and give a rapid result. Currently there is no such assay. In addition there would still be doubt regarding the in vivo efficacy of administering a greater dose of streptokinase calculated from the in vitro estimation of circulating antibodies to provide thrombolysis equivalent to a conventional first dose of streptokinase. Increasing the dose of streptokinase might also increase the risk of allergic reaction as well as stimulating further production of antibodies.

Patients who present with reinfarction require prompt assessment and effective thrombolytic therapy. Therefore it is advisable to avoid readministration of streptokinase or anistreplase until the role of anti-streptokinase antibodies in vivo is clarified. A non-antigenic thrombolytic agent such as alteplase should be used. Patients need to be aware of the importance of informing their doctors of previous streptokinase treatment and all patients should be encouraged to carry cards indicating the date they first received streptokinase.

1 Rivers JT, White HD, Cross HD, Williams BF, Norris RM. Reinfarction after thrombolytic therapy for acute myocardial infarction followed by conservative management: incidence and effect of smoking. $\mathcal{F} \mathrm{Am}$ Coll Cardiol 1990;16:340-8.

2 ISIS-2 (Second International Study of Infarct Survival) Collaborative Group. Randomised trial of intravenous streptokinase, oral aspirin, both, or neither among 17187 cases of suspected myocardial infarction. Lancet 1988;ii:349-60.

3 Ohman EM, Califf RM, Topol EJ, et al. Consequences of re-occlusion after successful reperfusion therapy in acute myocardial infarction. Circulation 1990;82: 781-91.

4 James DCO. Anti-streptokinase levels in various hospital patients groups. Postgrad Med F 1973;49(suppl):26-9.

Fletcher AP, Alkjaersig N, Sherry S. The maintenance of a sustained thrombolytic state in man. I. Induction and effects. F Clin Invest 1959;38:1111-9.

6 Verstaete $M$, Vermylen J, Amery A, Vermylen C. Thrombolytic therapy with streptokinase using a standard dosage scheme. $B$ Med $\mathcal{F}$ 1966;i:454-56.

7 Lynch M, Littler WA, Pentecost BL, Stockley RA. Immunoglobulin response to intravenous streptokinase in acute myocardial infarction. $\mathrm{Br}$ Heart $\mathcal{f} 1991 ; 66$ : 139-42.

8 Fears $R$, Ferres $H$, Glasgow E, Standring R, Hogg KJ, Gemmill JD, et al. Monitoring of streptokinase resisto titre in acute myocardial infarction patients up to 30 months after giving streptokinase or anistreplase and IgG. Br Heart $\mathcal{F}$ 1992;68:167-70.

9 McGrath KS, Patterson R. Anaphylactic reactivity to McGrath KS, Patterson R. Anaphylactic
streptokinase. $\mathscr{f} A M A$ 1984;252:1314-7.

streptokinase. $\mathcal{F} A M A 1984 ; 252: 1314-7$.
$10 \mathrm{McG}$ rath $\mathrm{K}$, Patterson $\mathrm{R}$. Immunology of streptokinase in human subjects. Clin Exp Immunol 1985;62:421-6.

11 Jalihal S, Morris GK. Antistreptokinase titres after intravenous streptokinase. Lancet 1990;335:184-5.

12 Buchalter MB, Suntharalingam G, Jennings I, Hart C, Luddington RJ, Chakraverty $R$, et al. Streptokinase resistance: when might streptokinase readministration be ineffective? Br Heart $\mathcal{F}$ 1992;68:449-53.

13 Gruppo Italiano per lo Studio Della Streptochinasi nell'Infarcto Miocardico (GISSI). Effectiveness of intravenous thrombolytic treatment in acute myocardial infarction. Lancet 1986;i:397-402.

14 Massel D, Turpie AGG, Gill JB, Cairns JA, Russett J. Development of neutralising antibodies after 1.5 million units of streptokinase in the treatment of acute myocardial infarction [abstr]. Circulation 1989;80(suppl II):350. Elliot JM, Cross DB, Cederholms-Williams S, White HD. Streptokinase titres 1 to 4 years after intravenous str
tokinase [abstr]. Circulation 1991;84(suppl II):216.

16 Massel D, Turpie, AGG, Cairns JA, Ofosu FA, Buchanan MR. Previous streptokinase (SK) therapy inhibits subsequent SK thrombolysis [abstr] Circulation 1991; 84(suppl II):216.

17 White HD, Cross DB, Williams BF, Norris RM. Safety and efficacy of repeat thrombolytic treatment after acute myocardial infarction. Br Heart $\mathcal{f}$ 1990;64:177-81. 